\title{
Puppets, Dogs, and Vegetarian Angels: Ecocriticism in Jakub Krofta's Polish Productions
}

Animals have been at the forefront of many current global legal, social, and environmental debates. Cutting down the rainforest and killing the animals' habitat; ritual slaughter; the environmental impact of eating meat; the use of animals for entertainment and research; or recent cases of legally recognising great apes and cetaceans as non-human persons, are only a selection of topics. The philosophical connection between these debates seems to be the need to renegotiate human-animal relations.

Traditionally, animals functioned as an 'object of rights vested in their human owners but not as the object of rights against human beings' (EPSTEIN 2004: 144), in other words: as properties existing for the use of humans. Today the need to protect animals seems socially accepted. Many countries, including the European Union, have recognised the status of animals as sentient beings and introduced animal welfare acts to protect them (EUROPEAN UNION 2007: 49). However, the current public debates on ritual slaughter (for example WYATT 2015) or the recent protests of French farmers against France finally legalising the status of animals as sentient beings (RFI 2015), show that the protection of animals becomes a contentious issue when it goes against human rights, such as the right to religious freedom or the right over property. At the same time, organisations like the Nonhuman Rights Project call for further strengthening of animals' status by legal recognition of animals as subjects of law that possess their own rights (NONHUMAN RIGHTS PROJECT 2013).

The above paragraphs do not attempt to convey the complexity of the debates on the status of animals. Instead, their purpose is to highlight that the renegotiation of the relations between humans and animals is at a crucial stage of its process; it also overlaps 
with key global debates. My opening also functions as a brief contextualisation to what will follow: a wider discussion of the ability of puppet theatre to contribute to this process, which is my essay's main focus. I am particularly interested in how interactive relationships between performers, puppets, and spectators can facilitate the renegotiation of relations between humans and animals in theatre for young audiences. My analysis concentrates on the work of the Czech theatre director Jakub Krofta in Polish puppetry theatres in the context of Greta Gaard's theories on ecopedagogy (GAARD 2009). The main purpose of this essay is to explore how the Czech director's creative use of puppetry techniques and aesthetics engages young spectators from Poland with global discussions relating to human/environment relations.

The two productions under examination have the human-dog relationship at their centre, as well as highlighting issues of humans' interactions with other animals. Dashenka, or the Life of a Puppy (Daszeńka, czyli żywot szczeniaka - an adaptation of Karel Čapek's famous story) was directed in 2011 for the Lalka Theatre (Teatr Lalka) in Warsaw. Pacan - a Story About Love (Pacan - historia o mitości) by Maria Wojtyszko was staged in 2012 by the Wrocław Puppet Theatre, or WTL (Wrocławski Teatr Lalek), of which Krofta is the Artistic Director. Both productions received excellent reviews. Pacan became one of the twelve finalists of the $19^{\text {th }}$ National Competition for Productions of Contemporary Polish Plays (Ogólnopolski Konkurs na Wystawienie Polskiej Sztuki Wspótczesnej) in 2013. However, before discussion can turn to the two productions, some cultural context is needed.

\section{Czech Puppetry Practitioners in Poland}

'In theatre the national differences, instead of dividing, are now connecting,' says Polish theatre critic Hanna Usarewicz at the end of her article on a significant presence of Czech and Slovak theatre practitioners on Polish stages (USAREWICZ 2012). ${ }^{1}$ In contrast to the complex political relations between the Polish and Czech peoples, in both current and historical contexts, Polish-Czech cultural exchange has recently been flourishing. In her article, Usarewicz talks about the Slovak scenographer Eva Farkašová, the director Ondrej Spišák (a frequent collaborator of Tadeusz Słobodzianek), the Czech-Slovak theatre team SKUTR (run by Lukáš Trpišovský and Martin Kukučka), and Jakub Krofta. Usarewicz also highlights the importance of artists from previous generations: Josef Krofta and Karel Brožek, the latter of whom was from 2007 to 2012 Deputy Artistic Director of the Silesian Puppet and Actor Theatre Ateneum (Ślaski Teatr Lalki i Aktora Ateneum) in Katowice. One important name that Usarowicz omits is the late Petr Nosálek, a Czech director who created approximately seventy productions on Polish stages, the majority of which were for puppetry theatres (INSTYTUT TEATRALNY 2014a).

1 Unless stated differently, all translations from Polish are provided by the author of this article. 
The names mentioned in Usarewicz's article suggest that the graduates of the Theatre Faculty of the Academy of Performing Arts (DAMU) in Prague, and its Department of Alternative and Puppet Theatre are particularly attracted by Polish theatre (for example Farkašová, Spišák, Trpišovský, Kukučka, and Jakub Krofta); or perhaps their innate skills and imaginations are attractive to Polish theatre. The roots of such a trend can be traced back to the 1975 Jánošík, co-created by three theatres: the Dragon (DRAK) Theatre from Hradec Králové (Czech Republic), the Puppet Theatre at the Crossroads (Bábkové divadlo na Rázcestí) in Bánská Bystrica (Slovakia), and the Puppets and Actors Theatre (Teatr Animacji - teatr lalki i aktora) in Poznań (Poland). According to DRAK Theatre's website, the production about Jánošík (to put it very simply, a Slovak-Polish-Czech Robin Hood) ${ }^{2}$ was 'the first international project in the modern history of puppet theatre' (KROFTA 2014). Both Josef Krofta and Karel Brožek started their Polish artistic collaborations by directing parts of Jánošík. By bringing Josef Krofta to Poland, the production has indirectly brought many contemporary Czech and Slovak theatre practitioners to Poland.

Josef Krofta, former head of the DAMU's Department of Alternative and Puppet Theatre, until his death in 2015, co-led the course in Directing for Alternative and Puppet Theatre, together with Marek Bečka (DAMU 2014). He was one of the artists and pedagogues responsible for the cooperation between DAMU and the Puppetry Department of the Ludwik Solski State Drama School in Wrocław (PWST). The 2004 Massacre, devised by the students of both schools and based on folk ballads from the Polish-Slovak-Czech border region, became one of the first products of the DAMU-PWST partnership; Josef Krofta was amongst the supervisors. Massacre started SKUTR's collaboration with Polish artists; these days Trpišovský and Kukučka lecture at DAMU and bring their own students to Poland (USAREWICZ 2014). The scenographer, Jan Polívka, decided to pursue his career in Poland and, to date, created scenography for approximately sixty Polish productions in puppetry and dramatic theatres (INSTYTUT TEATRALNY 2014b).

The work of Jakub (son of Josef) Krofta in Poland is another, even stronger, example of the 1975 Jánošík's impact upon the collaborations between Polish, Czech, and Slovak theatres. Jakub Krofta, like Spišák and Farkašová, was invited to Poland by the Lalka Theatre in Warsaw. He came in 2006 to stage Josef Kainar's Goldilocks (Zlatovláska) as an already experienced director. His career started in 1993, when, as a student of DAMU, he directed the Spoon River Anthology (Spoonriverská antologie) for the Dejvice Theatre in Prague. The production was based on the collection of poems by E. L. Masters, under

2 Juraj Jánošík (1688-1713) was a famous Slovak highwayman. In his youth he fought with the Kuruk peasant insurgents against the Habsburg forces that controlled the Habsburg Monarchy's Kingdom of Hungary area (roughly the area covered by modern day Hungary, Slovakia and Transylvania). He later joined the Habsburg Army, before finally setting up a gang of highwaymen, of which he took sole command at the age of 23. The group was active mostly in North-Western Kingdom of Hungary (today's Slovakia), around the Váh (Vág) river between Važec (Vázsec) and Východná (Vichodna), but the territory of their activity extended also to other parts of the modern Slovakia, as well as to Poland and Moravia. In 1974 Polish National Television (TVP) produced a cult television series based on Jánošík's adventure, directed by Jerzy Passendorfer. 
the same title, adapted for stage by Jakub Krofta and Marek Zákostelecký; it remained in the theatre's repertoire until May 1997 (DEJVICE THEATRE 2014).

By the time Jakub Krofta came to Poland, he had also directed his original - and perhaps his best known - production Everything Flies that Has Wings (V̌̌echno lítá, co peři má), presented in English as The Flying Babies (2000). The production, aimed at an audience of three-year-olds and older, tells a story (without words) about three infants looking for their balloon. To date, The Flying Babies has had more than six hundred performances (WTL 2014a). The production has travelled around the world, including to Scotland (2003, Royal Lyceum, Edinburgh, and Eden Court Theatre, Inverness), England (2005, The Junction, Cambridge), Australia (2004, Windmill Performing Arts Season, Adelaide), and, most recently, Italy (2014, International Festival of Theatre and Culture for Early Childhood, Bologna). The Flying Babies was awarded prizes at international festivals in Poland and Slovenia (DRAK THEATRE 2015). In 2008, Jakub Krofta became the Artistic Director of DRAK Theatre (DRAK THEATRE 2014).

In 2010 Krofta came back to Warsaw to direct Everything Flies that Has Wings (Wszystko lata, co ma skrzydła) based on The Flying Babies, for the Puppet Theatre Gulliver [Teatr Guliwer] in Warsaw. His third theatrical collaboration with Poland brought him back to the Lalka Theatre and the 1975 Jánošík. As Krofta recalls, he and Ondrej Spišák - the Artistic Director of the Karol Spišák Old Theatre in Nitra (Staré divadlo Karola Spišáka) were inspired by the 1975 project. They approached the Lalka Theatre and the Polish director Łukasz Kłos with the idea for a Czech-Polish-Slovak production performed by a multinational cast (KROFTA 2014). Jánošík, Janosik, Jánošík used the legend of Jánošík to explore national myths and stereotypes, showing, to bring us back to the opening quotation, that 'in theatre, national differences are not dividing, but connecting' (USAREWICZ 2012). Jánošík, Janosik, Jánošík premiered in Terchová (the birthplace of the historic Jánošík) in April 2010 and was performed in Poland, Slovakia, and, Czech Republic (KROFTA 2014).

Collaborations with the Lalka Theatre led to another production: Dashenka, or the Life of a Puppy (Daszeńka czyli żywot szczeniaka), premiered in May 2011. A year later, Jakub Krofta was announced the new Artistic Director of the Wrocław Puppet Theatre (WTL). During the summer of 2012 he directed Madame by Antoni Libera (adapted for the stage by Maria Wojtyszko) for the Dramatyczny Theatre in Warsaw. His staging of Wojtyszko's Pacan - a Story About Love was Krofta's first production as the Artistic Director of the WTL; it premiered in November 2012. The three shows mark Krofta's increasing engagement with Polish audiences - and young audiences in particular - not only in terms of aesthetics and entertainment, but also in terms of social discussions. Madame translated the every-day reality of communist Poland for Polish teenagers (CZAJKOWSKA 2012). Theatrical explorations of human-animal relationships in Daszeńka and Pacan were respectively aimed at spectators who were at least four years old (LALKA 2014) and eight years old (WTL 2014b). 
I will now turn to Greta Gaard's ideas about ecopedagogy. Her theory will underlie my analysis of Daszeńka and Pacan as examples of Krofta's innovative engagement with the social and theatrical education of young Poles.

\section{Ecopedagogy and Puppetry Theatre}

Greta Gaard explains that ecopedagogy grows out of child-focused ecocriticism that interrogates links between nature and culture 'through the relationships of children and animals, with particular scrutiny on the subjectivity or objectivity of the animals depicted in these narratives' (GAARD 2009: 325). Ecopedagogy mixes ecocriticism with practice; that is, it not only explores the problematic 'logic of domination' on the basis of which humans are allowed to abuse other animals and the environment, but also points out the possible solutions to it (GAARD 2009: 323, 328, 332). As Gaard puts it:

ecopedagogy emphasises the need for action, commitment, change - now! It asks for personal and socio-political changes for the health of the earth as well as its inhabitants. It can include those types of ecocriticism that are more than mere scholarship - but they must be activist in orientation, dedicated to teaching children and their adults the strategies of sustainability, connection, and democratic community-building that considers and involves all life on earth. (GAARD 2009: 333-4)

Through its focus on the future, solutions, and the urgency to act, ecopedagogy aims at disrupting the 'logic of domination' and at reframing humans' interactions with animals and nature in general. The key part of the process is the exploration of animal agency (GAARD 2009: 331).

Agency is of course a very problematic term. Sarah E. McFarland and Ryan Hediger point out that even if we apply a very general idea of the agency as one's capacity to act on one's own behalf and to engage in one's own interests, we will still encounter issues of a particular animal and particular circumstances, which raise a question of how much of another being, whether human or animal, we can understand (MCFARLAND and HEDIGER 2009: 8-9 and 16). On the other hand, McFarland and Hediger refer to Martha Nussbaum's idea that an animal as an agent conveys 'a creature who is itself an end' (NUSSBAUM 2009: 337), rather than as existing for humans. In other words, the idea of animal agency opens questions about our understanding of the relationships between humans and other animals, which is how McFarland and Hediger justify their choice to use the above account of agency and explore it 'in a case-by-case, unique-in-eachinstance-fashion' (MCFARLAND and HEDIGER 2009: 15-6). I will follow their idea.

According to Gaard, ecopedagogy has a particular potential to explore animal agency, which in turn gives it a special position within the broader environmental movements. 
'The first and strongest emotional connection with nature may be children's innate love of animals', says Gaard, which allows ecopedagogy to 'address children's emotions and make deep, lasting impacts because it appeals to both the emotions and the intellect' (GAARD 2009: 332). Gaard focuses on literature, perhaps because in terms of ecocriticism, and child-focused ecocriticism in particular, literary studies are more developed than theatre studies. Ecocriticism, in general, has been playing a minor part within theatre studies, which ironically links with theatre for young audiences. However, Gaard's main points are in line with Helen Nicholson's argument that theatre, when united with education and social justice, is 'politically charged' and has unique potential to educate by focusing on the future and to offer 'a vision of social change' (NICHOLSON 2009: 11-3).

According to Nicholson, the particular power of theatre grows out of the political and social value of imagination as it is expanded through theatre's aesthetics; in theatre, the imaginations of artists and spectators combine to fill the gap between reality and fiction. Because of that, Nicholson explains, theatre can invite the audience 'to imagine that which was previously unimagined or unimaginable', which, in turn, challenges existing ideas and values and may evoke social change (NICHOLSON 2009: 47-51). As a result, theatre can provide young spectators with tools to interpret globalised society critically and creatively and can present them with 'imaginative insights into another world which, once seen, cannot be unseen' (NICHOLSON 2009: 58). Theatre's role and responsibility links with another of Nicholson's points: she highlights that theatre is a particularly 'memorable medium' (NICHOLSON 2009: 5). In other words the audience's encounter with live performance may last longer than the performance itself. In fact, as Karen Burland and Stephanie Pitts explain, our memories of live performances may become 'entwined with our biographies' (BURLAND and PITTS 2014: 176). The point is that a re-imagined reality, encountered in performance, may continue to affect the spectators throughout their lives.

All of this suggests that ecopedagogy in theatre may be remarkably powerful. If animal agency escapes our understanding, perhaps theatre can stimulate the imagining of it; in turn, our imagination, combined with theatre's memorability can affect our understanding of animal agency and reshape our relations with other animals. Puppet theatre, through its particular engagement with creating agency, can offer a unique contribution to that process, as I will now explain.

Susan Bennett remarks that the interactions between audience and actors constitute one of the three key relations in which spectators are involved during live performance (BENNETT 1997: 151). However, as pointed out by Helena Waszkiel, an eminent Polish theatre critic, in puppet theatre, there is another participant, 'an animated form' livened up through animation (WASZKIEL 2014). Paul Piris describes the puppet as 'an object that appears in performance as a subject' (PIRIS 2014: 30). The puppet in performance seems to act on its own behalf, but, as Penny Francis explains, for the puppet to gain agency, it must detach itself from 'any external control' (FRANCIS 2012: 139). In other words, the manipulator must 'disappear'. The puppeteers transfer their presence into the 
puppet (FRANCIS 2012: 93). This creates a bond between the puppet and the puppeteer that is both material and ethereal, which is 'the essence of puppetry', says Waszkiel, quoted by Francis (FRANCIS 2012: 29). Piris's arguments, however, highlights that the art of the puppeteer is not enough for the puppet to gain agency; it is the audience that imagines the agency of the puppet (PIRIS 2014: 40). Thus, the essence of puppetry is the bond between the puppet, the puppeteer, and the audience, which unites the puppeteer's skills with the collective and individual imaginations of the puppeteer and the spectators and, in turn, creates the agency of the puppet.

I do not attempt to create links between animals and puppets. Instead, I am interested in puppetry theatre as a mode of performance that is particularly suited to facilitating the process by which agency can be imagined and sustained. I will next argue that in Daszeńka and Pacan Krofta innovatively uses the power and the principles of a puppeteer-puppet-audience relationship to fuel the audience's imagination, so they can explore relationships between humans and other animals as interactions between different agencies. However, because the essence of Krofta's approach lies in the co-presence between spectators, actors, and puppets, some further theorisation is needed.

Paul Piris, in his discussion on the co-presence between the puppet and the puppeteer, says that such phenomenon occurs when 'the performer creates a character through the puppet but also appears as another character whose presence next to the puppet has a dramaturgical meaning. Co-presence of this sort requires special skills from the performers because they have to ensure that the audience engages with both the performer and the puppet (PIRIS 2014: 31). In the situation of co-presence, the puppet gains a particular agency, which is achieved not only through skilful manipulation, but also through the interactions between the puppet and the human being (the performer). 'The apparent body of the puppet' and the actual body of the performer are presented as separated and yet, through their interactions, both in presence, which creates 'the epiphany of apparent consciousness in the puppet' (PIRIS 2014: 37). In other words, the co-presence between the puppet and the puppeteer additionally stimulates the audience to imagine the agency of the puppet.

The coexistence of puppets and humans is not untypical for Krofta's style and that of DRAK Theatre. Penny Francis remarks that in DRAK; Theatre's productions 'the presence of the puppets alongside the performers always had dramaturgical quality' (FRANCIS 2012: 113). In Daszeńka, Krofta combines his techniques and aesthetics to establish very rich and multi-layered co-presence between actors, puppets, and audience. Because of that, Daszeńka will be my main focus. In Pacan, Krofta plays with audience-actor relationships and there is only one case of a co-presence between the puppets and the actors; however the moment is critical for the production's engagement with animalhuman relations. In both productions, Krofta employs creative strategies to enhance the memorability of the performances. By extension, Daszeńka and Pacan become powerful examples of the ecopedagogical potential of puppet theatre. 


\section{Daszeñka: Respectful Interactions and Collective Responsibilities}

Karel Čapek wrote, illustrated, and photographed a story about a fox terrier puppy growing up under the title Dashenka, or the Life of a Puppy (Dášeňka čili Život štěněte). The 1933 novel is narrated by a man and offers his observations of the puppy, an account of his verbal and non-verbal interaction with Dášeňka, and fairy tales for dogs told to Dášenka by the narrator. The amusing fairy tales focus on the origins of dog-human relations and on the development of dogs' behaviours, for instance fox terriers' love for digging. The novel was translated to Polish by Jadwiga Bułakowska and first published by Nasza Księgarnia in 1950 under the title Daszeńka, czyli żywot szczeniaka. In 1979, the book was turned into a television series by Květa Kuršová a Břetislav Pojar; Pojar directed it for the Czechoslovak Television ČST (ČESKÁ TELEVIZE 2014). The dog in the televised adaptation, a mixture of cartoon and film, strikingly resembled the fox terrier from Čapek's photograph.

Pojar's series was broadcasted in the early 1980s by Polish National Television (TVP), as part of the series Good Night Story (Dobranocka). Good Night Story was a popular evening programme for children starting at $7 \mathrm{pm}$ and one of the most important pop culture phenomena of communist Poland, particularly for the Polish generation of the 1970s and 1980s (KOZICZYŃSKI 2009: 78-9). Arguably, many of the parents who accompanied their children to Krofta's staging of Daszeńka had in the past been glued to the television screen watching the adventures of the puppy. Thus the production potentially had an immediate appeal to those buying tickets by inviting them on a sentimental journey, especially given that Krofta adapted the well-known Bułakowska's translation. For instance, the reviewer Agnieszka Szydłowska experienced such a sentimental journey and started her review by recalling the famous opening of Čapek's book (SZYDŁOWSKA 2011).

The performance does not start, however, from the well-known opening: 'When it was first born it was just a white bit of nothing' (Gdy się urodzito to było to takie biate nic) (ČAPEK 2013: 7). Instead, within a conventional proscenium space, with drawn curtains, there is a spotlight and simple, melodic music, composed by Paweł Łuczak, playing in the background. In the archival recording of the production, one can also hear the excited voices of the young spectators. The spotlight increases in intensity and male and female voices are heard saying 'Good Morning. The four actors - Monika Babula, Aneta Harasimczuk, Wojciech Pałęcki, and Piotr Tworek - come into the spotlight and welcome the audience by waving, smiling, and saying they are really happy to see them. They all are wearing exaggerated versions of contemporary clothing in various shades of blue, red, and cream (designed by Slovak scenographer Zoja Zupková and visible on the photograph from the ending of the production , Fig. 1) (WARZECHA 2011). They look as if they are dressed up to play a family. 


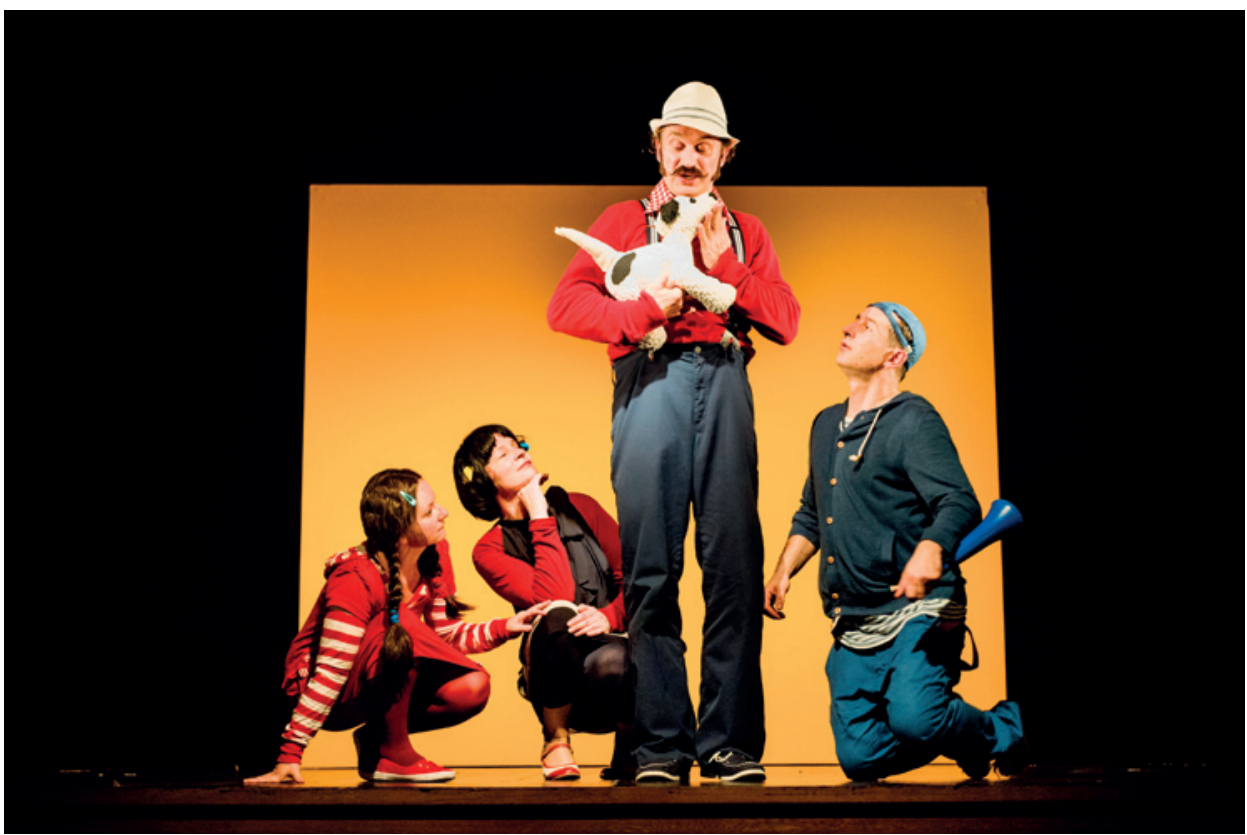

Fig. 1: Monika Babula, Aneta Harasimczuk, Wojciech Pałęcki, and Piotr Tworek in Jakub Krofta’s staging of Daszeńka. Photo (c) Bartek Warzecha, reproduced with permission.

Pałęcki asks if anyone has a dog, introducing the main theme of the performance. The question immediately evokes replies, given through raised hands and voices. The actors engage with spectators individually and encourage responses, either through eye contact and hand gestures, or through questions - for example Harasimczuk asks some of the children: 'What dog do you have?' Through the interactions, the actors carefully direct the discussion towards the responsibilities attached to having a dog. They suggest that children want to play with dogs, but do not look after dogs. In other words, the dogs are treated like toys or objects.

As the conversation progresses, the children become braver in their responses. And, when Harasimczuk introduces the story that the actors are going to tell, some children immediately shout the name: 'Daszeńka'. The actors explain their parts in the story and make it clear to the children that they will be only playing their roles. Harasimczuk will be a mother; Pałęcki will play a father; Babula and Tworek will play daughter and son respectively. The actors start the story by saying that mother Iris gave birth to Daszeńka.

My detailed description of the opening has a point. The start of Daszeńka carefully frames the audience encounter with the performance and its themes. Firstly, the opening marks the objectification of animals as a problem in the young audiences' 


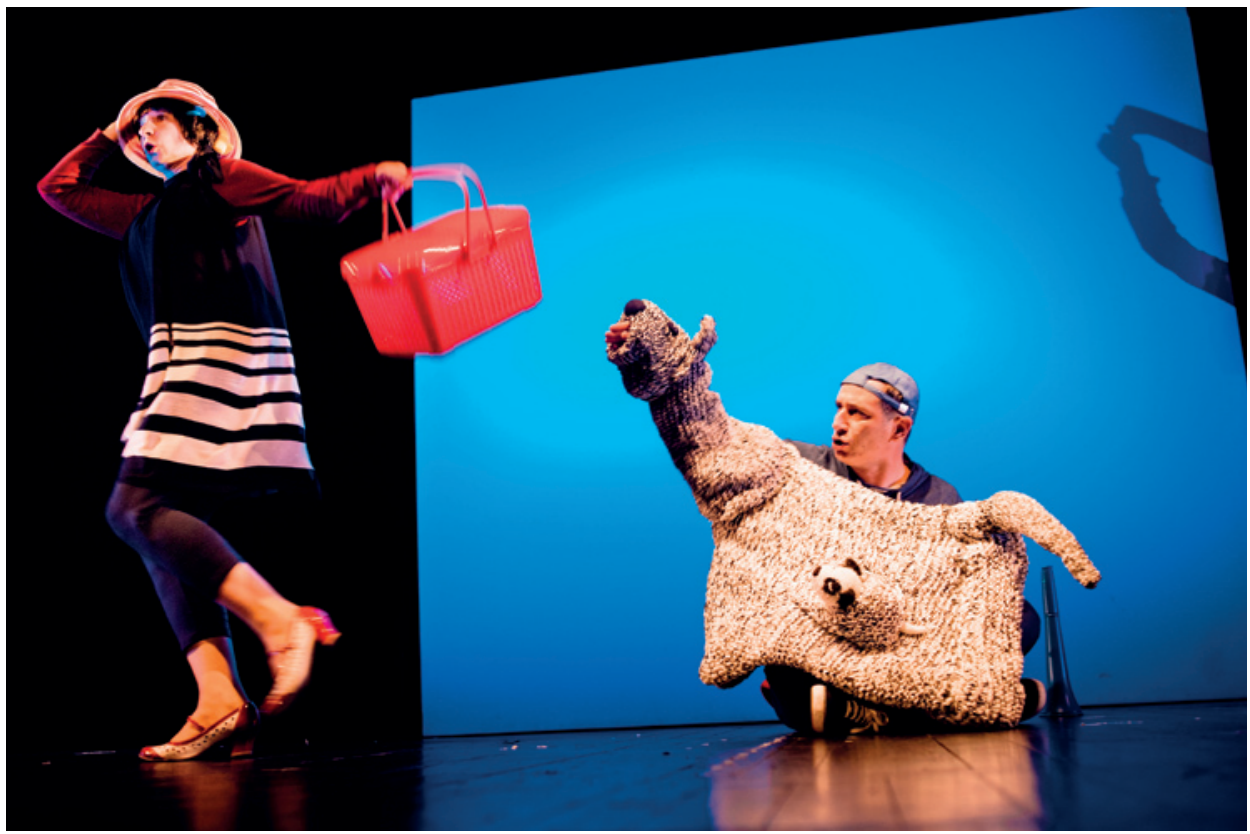

Fig. 2: Piotr Tworek manipulates a woolly jumper puppet Iris, with Daszeńka tucked up in a pocket, while Aneta Harasimczuk runs away. Photograph (c) Bartek Warzecha, reproduced with permission.

interaction with dogs, which is one of the ecopedagogical tasks (GAARD 2009: 332). Secondly, it establishes Krofta's key strategies to engage the performance's youngest spectators: interaction and play. Both are crucial for the aesthetic experience of young audiences and for the ecopedagogical aims of the production, as I will now discuss using Nellie McCaslin's and Jeanne Klein's analyses of aesthetics in theatre for young audiences.

Nellie McCaslin explains that participatory theatre is very appealing to very young children as it 'is similar to their own play'; participatory theatre offers its young audiences 'a dual experience - as spectators and as participants' (McCASLIN 2005: 17), which is visible in the opening of Daszeńka. McCaslin's arguments are also in line with Bennett's point that, in general, the spectators 'stripped' from their invisibility are empowered because they are reminded that they are the ones who ultimately decide on the meanings and success of the performance (BENNETT 1997: 124, 133, 156). Of course, the levels of responsibility given to the audience may vary depending on the age of spectators. However, the key point is that interactions and play are aesthetically very appropriate for very young audiences; they also provide the children with agency and a certain responsibility for their action, as well as for the shape of the performance.

The participatory and playful qualities of Daszeńka also fuel the audience's imagination, which is crucial to the performance achieving its ecopedagogical aims. Very young 
audiences are very sensitive to the differences between the supposed reality presented on the stage and the 'actual world', explains Jeanne Klein (KLEIN 2005: 48). However, McCaslin remarks that 'when a theatrical convention is employed openly and honestly', as the frame of play is introduced in Daszeńka, young spectators understand and respect it, even if certain elements of the production are not 'realistic' (McCASLIN 2005: 17). Consequently, the spectators of Daszeńka can engage in the interactive play with the four actors, which is sustained throughout the performance. Following McCaslin's points, 'the imagined reality' that starts in this play has a power to captivate the audience and encourage them to go on a journey 'to another place, another time, on an adventure'; what follows is therefore 'a new way of looking at things' (McCASLIN 2005: 15). To sum up, the opening of Daszeńka creates the perfect environment to facilitate change through the combined imaginations of the spectators and actors.

Krofta builds on the start of the performance to establish a unique co-presence between the puppets, all actors and, as the performance progresses, the audience. For a start, the puppets of the little dog Daszeńka and her mother Iris (designed by Zoja Zupková) are animated by all four actors who, at the same time, enact their own characters. Iris is performed by a large hand puppet that looks as if it was made from a huge wool jumper. The puppet has a pocket, in which the actors sometimes place the puppet of Daszeńka, highlighting the bond between the mother and the daughter. The Iris puppet is animated through its head and tail; its mouth is moveable and the hand of an actor manipulating it performs as Iris's tongue. Different actors perform Iris throughout the performance, usually one or two at a time. The co-presence between actors and puppet is particularly striking when one actor animates Iris while the other is creating the sounds.

For instance, Babula, narrating the story, talks about Iris looking after Daszeńka, while animating the puppet, so it looks like Iris is licking Daszeńka, placed at that stage in Iris's pocket. Babula's body seems separated from the body of Iris because Babula directs her speech at the audience, while her gaze moves from the audience to Iris, on whose actions she comments. Iris's gaze is focused only on Daszeńka. At the same time, Tworek uses his vuvuzela to make sounds of Iris's breathing and licking. Tworek's face is turned away from the audience as he looks at Iris, as if observing her actions, which makes the source of Iris's sounds less visible; the vuvuzela additionally covers Tworek's mouth. The actors simultaneously perform the action of their characters, while animating the puppet in a way that separates the source of Iris's movement from the source of her sounds and also hides both sources. Iris thus seems to co-exist on the stage both independently from and together with Babula and Tworek. Moreover, the joyful noises of children in reaction to Iris licking Daszeńka confirm that the puppet appears to the audience to be behaving on its own behalf. Iris's agency is confirmed by two actors' and the audience interactions with her. As a result, and in accordance with Piris's earlier points (PIRIS 2014: 37), Babula, Tworek, and the young spectators establish a co-presence with the puppet. The puppet becomes the dog that children can engage with. 
Iris's agency is strengthened when all four actors enact Iris trying to protect Daszeńka from strangers by barking and biting while they simultaneously also perform various characters' reactions to it. Harasimczuk and Pałęcki, with circus music in the background, enact various characters, for example a lady with a basket, or an older man. Iris, manipulated by Tworek, bites, growls, and pulls the old man's walking stick and the lady's basket. Although only one actor manipulates the puppet, all the actors perform actions that serve to animate her. Harasimczuk's and Pałęcki's bodies perform the strength of Iris's pulling. Babula performs Iris's aggressiveness, by trying, as the Daughter, to calm her down. Iris's emotions, sounds, and physicality come from four different sources that are covered up by the actors' simultaneous performances as the characters, and also by the dynamics of the scene. In short, we are dealing here with a multi-layered and dense co-presence between the puppet and four performers, which allows a big wool jumper to become a big, loud, angry, and, most importantly, uncontrollable dog. Iris's aggressiveness is earlier explained by the 'Voice of Nature' (delivered by Tworek through his vuvuzela), which tells Iris to protect the helpless Daszeńka. Thus the point is made that Iris is not an aggressive dog, but the protective mother must be approached with caution.

The appearance of the 'Voice of Nature' also suggests that animal agency is controlled by nature, which may be limiting animal agency to instinct; however the simplicity of its explanation seems appropriate for very young spectators. We must also remember that Daszeńka does not attempt to explore the complexity of agency and nature. Instead the production works against the idea of a dog as a toy, and educates children about how to interact with animals in a respectful manner. The 'Voice of Nature', by contextualising Iris's behaviour, thus works towards the same aim.

Krofta's exploration of co-presence between multiple actors, the puppets, and the audiences is further developed in the animation of Daszeńka. There are at least five hand-held puppets that perform Daszeńka at different stages of the puppy's growth. In Daszeńka’s first appearance Harasimczuk carries the smallest of Daszeńka puppets in her hands. Harasimczuk, as the Mother, moves her hands slowly as if she was stroking the puppy, which covers the other movement of Harasimczuk's hand (which animates the puppet's body), so it looks as if Daszeńka is breathing. The puppet's agency, similarly to Iris's agency, is thus created through an ostensible separation of Daszeńka's breathing from Harasimczuk's gestures as the Mother and through the co-presence of Daszeńka with all four actors that react to Daszeńka's first movements. The actors also take turns in narrating the story, which are the only moments that they turn their eyes away from the puppet and towards the audience to include them in the experience and communicate the importance of the puppy. The actors' movements, both as puppeteers and as characters, are slow, gentle and cautious, and they gather closely to the puppet. Their kinaesthetic and proxemic relationships towards the puppet help to represent the vulnerability of the new-born puppy - a fragility that is that dependent on humans, which is reinforced by the actors saying that the newborn Daszeńka 'was quite blind' (ČAPEK 2013: 7). 
Later on, when Daszeńka is portrayed by one of the bigger puppets, the audience sees the family asleep on the stage, while Daszeńka 'walks' and 'runs' on the humans. Pałęcki (the Father) is spread across the stage. The other actors pretend to sleep behind him and use him as a 'pillow'. The body of Pałęcki functions here as a form of screen, behind which the other actors manipulate at least two identical Daszeńka puppets. As a result, Daszeńka can appear at different parts of Pałęcki’s body at short intervals; Daszeńka seems to run freely and is also more independent from the humans. In another moment, Babula, as the Daughter, mops the floor after the puppy urinated. She holds the mop in both hands and has the Daszeńka puppet on one of them, so it looks like Daszeńka holds to the mop with her teeth. The audience understand that the puppy pulls the mop when Babula moves her body as if it was being pulled.

The contrast between the initial and later appearances of Daszeńka creates the impression that Daszeńka grows in front of the audience's eyes. The effect is achieved by the gradually increasing dynamics of the actors' animation and proxemics between the subsequent Daszeńka's puppets and the actors-as-characters, as discussed. The young audience's responses to Daszeńka also change, rising from observations, through direct interactions, up to emotional engagement; the latter of which being important in the realisation of ecopedagogical aims (GAARD 2009: 332). 'She woke up', observes a quiet voice during the first appearance of the puppy. 'Daszeńka was naughty', says one of the children in the audience, when the Father lectures the puppy. Later on, when Daszeńka pees on the floor again, several children say 'Daszeńka you cannot do that'. At the end, when Daszeńka, adopted by a new family, disappears, there is a lot of crying in the auditorium.

In other words, the multiple co-presences between each of Daszeńka's puppets, the actors, and the spectators seem to have a different quality. However, each of the puppets represents one Daszeńka and actors-as-characters refer to each puppet as if it was the same dog, which confirms that each puppet represents the same agency. As a result, the living creature 'Daszeńka' (in conceptual terms) detaches herself not only from the bodies of the puppeteers, but also from the apparent bodies of the puppets that represent her. As the audience's imagination operates at a high level of intensity, stimulated by the aesthetic devices of play and participatory theatre, the dog's agency can be imagined and expanded through the imagined and increasing agency of the puppets. In the mop scene, Daszeńka's agency expands to the level at which it seems that the dog is manipulating the actors and not the other way around, as noted by one of the reviews (DERKACZEW 2011). The agency of the animal thus dominates the agency of the human, which links Daszeńka with Gaard's ecopedagogical aims.

The double-imagined agency of Daszeńka helps the performance to reframe relations between humans and animals. In Krofta's production, interactions between the family and both dogs (Iris and Daszeńka) are underlined by respect and responsibility. For instance, when Iris and Daszeńka are asleep, just after Daszeńka was born, the actors walk 
slowly, shushing the audience and each other; when the Son (played by Tworek) makes a noise by dropping his vuvuzela the entire family looks at him with disapproval. They are quiet so as to respect Iris's right to rest. Another example is the cleaning scene, in which everyone helps to clean multiple puddles of urine left by the puppy. In the reality created on the stage every single household member, including Iris, plays a part in Daszeńka's upbringing. The already quoted reactions of the young spectators confirm that they also accept their responsibility for Daszeńka's behaviour ('Daszeńka you cannot do that').

This sense of collective responsibility connects with the intergenerational feeling that the performance creates through comedy, which is particularly evident in the fairy tales about dogs told to Daszeńka. In those fairy tales the dogs are performed by actors, rather than puppets, creating a clear division between the 'reality' of the puppet enacted play and the humanly acted fairy tales within it. This division also pertains between the 'real' dogs (the puppets) and the pretend dogs (the actors). For example, there is a fairy tale about a dog that ate a blade of bad grass. The children may laugh at Tworek performing a dog, which, after eating grass, thinks he is a prince wearing golden heels. Donald Capps explains that very young children react with laughter to absurd situations, because laughter allows them to overcome their anxiety of not understanding the world (CAPPS 2006: 129). The adults are likely to understand the joke differently, since the Polish word 'trawa' denotes both grass and cannabis, there is a further level of multiple meaning. By extension, while different members of the audience may engage with the joke on different levels, the point is that they are laughing together and that such laughter creates a sense of community (MAY 2006: 191). And Daszeńka's audiences laugh frequently, as has been highlighted by the reviewers (DERKACZEW 2011 and ZAWORSKA 2011).

Such a collective experience may be strengthened by the sentimental value of Bułakowska’s translation and Zupkovás puppets' similarity to Daszeńka from Čapek’s photographs and in Pojar's series. By extension, there is a potential for the older spectators to engage with the performance and perhaps be reminded how some of them wanted a dog when they were children, as was the case for one of the reviewers (SZYDEOWSKA 2011). By creating a collective experience for children and their adult minders, the production also encourages a dialogue about the issues it raises. Such conversations would extend audience encounters with ecopedagogical themes beyond the timeframe of performance and, potentially, enhance its memorability. Consequently - in accordance with Burland's, Pitts's, and Nicholson's earlier points - dog-human relations, as re-imagined through the performance, would have stronger impact on the spectators in their everyday life.

Importantly however, the topics for discussion suggested by Daszeńka do not only concern dogs. In one of the fairy tales told to Daszeńka, vegetarian angels appear. They look after the first fox terrier created by God, the Fox (Babula). In Paradise, the Fox is not allowed to play and the meals consist of cheese and cream, because the Angels are 
vegetarian. The Fox plays with little devils outside Paradise and, after the attempt to sneak one of them in, the Angels (in Čapek's story it is the Creator) decide that dogs are more suited to live with humans. The fairy tale plays on Adam and Eve's banishment from Eden, which once again, on another level, may be quite engaging for the adults, as well as suggesting connections between humans and dogs that both belong somewhere between good and evil. Although the production does not promote a vegetarian diet or ethics, the story about the Fox associates vegetarianism with certain ethical superiority (Angelhood). It also introduces the idea of a vegetarian diet to the children and, arguably, provokes questions afterwards.

Krofta’s Daszeńka does not engage with environmental issues on a large scale. Instead it does something potentially much more important in that it mobilises a small, yet significant change in the relationship between humans and animals. Krofta thus builds on several things: the receptive strategies that his young spectators have already developed, on the children's love of and longing for dogs, on the possibilities inherent in puppet theatre to separate out several layers of signification, and on the skills of his actors to mark a problem within child-animal relations and to offer immediate and long-term solutions to it for both children and adults. Daszeńka invites the audiences to imagine a democratic community that includes children, adults, and animals and to create the sense of collective responsibility for human-animal relations. Multiple and multi-layered co-presences between the actors, the puppets, and the spectators facilitate the interplay between the characters, the dogs, and children through which spectators and Daszeńka learn. While human children and dog children are different, they all learn quickly and through interactions with others. The urgency to teach children responsible and respectful interactions with animals is encoded in Daszeńka's growth and her processes of learning. Daszeńka is not a call for environmental protest, but a call for responsible interactions, a sentiment repeated by Tworek through the vuvuzela at the very end. Daszeńka is a call for a discussion about having a dog, but also about humans and animals in general.

\section{Pacan: An Emotional Call for Help to Encourage Adoption}

Pacan was Krofta's first production as the newly appointed Artistic Director of the Wrockaw Puppet Theatre. The production once again features collaboration between Krofta, Maria Wojtyszko, and Zoja Zupková. Wojtyszko's play is based on her own experience of adopting from a shelter a dog whose anxieties she was trying to understand (MATUSZEWSKA 2011). It focuses on the adventures of a dog called Pacan looking for Marcin (his human minder), who went away for a weekend, but Pacan thinks he got lost. Searching for his human, Pacan himself gets lost. Scared, hungry, attacked by an aggressive bulldog and by the bulldog's owner, he finally ends up in a shelter, together 
with other dogs, ferrets, and an elephant. Pacan, who in the shelter falls in love with a female greyhound called Princess, finds his happy ending when Marcin visits the shelter. Although Marcin does not recognise Pacan instantly, he finally realises that this is his long-lost friend and takes Pacan, Princess, and their puppies, home. He also promises to find good families for the puppies after they grow up.

In Daszeńka the enhanced co-presences worked to give agency to the dogs. In Pacan limited co-presence, which occurs only once, operates as a means to give agency to the audience, so that they can oppose the cruelty of humans towards animals. In working towards that effect, Krofta, as in Daszeńka, engages the audiences' imagination by playing with age-appropriate aesthetics. Pacan is advertised for audiences of eight years and up. By that age, as explained by Jeanne Klein, children can engage with plot-driven situations, characters, and their subtexts. They continue to be engaged with a 'realistic' portrayal of the world, with believable characterisations being a criterion. The live actors and believable emotions performed by them are particularly attractive to children aged between six and twelve (KLEIN 2010: 117-9). Krofta facilitates this dynamic by using live actors for most of the characters, both humans and animals. However, through visual elements and specific casting choices, his production also works to facilitate the audience's critical engagement with the human characters and their actions, and emotional engagement with the animal characters. Both types of involvement are crucial in ecopedagogical processes (GAARD 2009: 332).

All human characters, with two exceptions, are performed by just two actors: Marta Kwiek and Marek Koziarczyk. Although the roles created by the actors are expressive and varied, they are all linked to each other through the actors that perform them. As has been pointed out by several critics, Bert O. States for instance, the audience never forgets about the actor in favour of the character (STATES 1985: 119). In addition, their costumes are very similar as Zoja Zupková dresses all human characters in black and white. The dominant colour in their costumes is white, which reflects stage lighting and 'washes out' Kwiek's and Koziarczyk's faces. As a result, their expressions are less visible; sometimes one cannot see them at all, as when Kwiek performs the Lady who finds Pacan (character name, played by Marek Tatko) on the street and brings him to the shelter. In this role, she wears a huge hat that completely covers her face. As a result of this diminution of the presence of the actors' human presence, the non-animal characters look very similar, which encourages the audience to perceive them as a group rather than as individuals, and discourages emotional involvement. Moreover, the fact that Kwiek and Koziarczyk perform the majority of human roles also highlights their identity as the actors, which, in turn, establishes certain aesthetic distance that works towards the spectators' intellectual (rather than emotional) engagement with human characters and their actions.

In contrast, the presentation of animal characters works to build an emotional connection between them and the audience. For a start, animal characters feature in the story much more often than humans. They are also individualised. Each is played by 


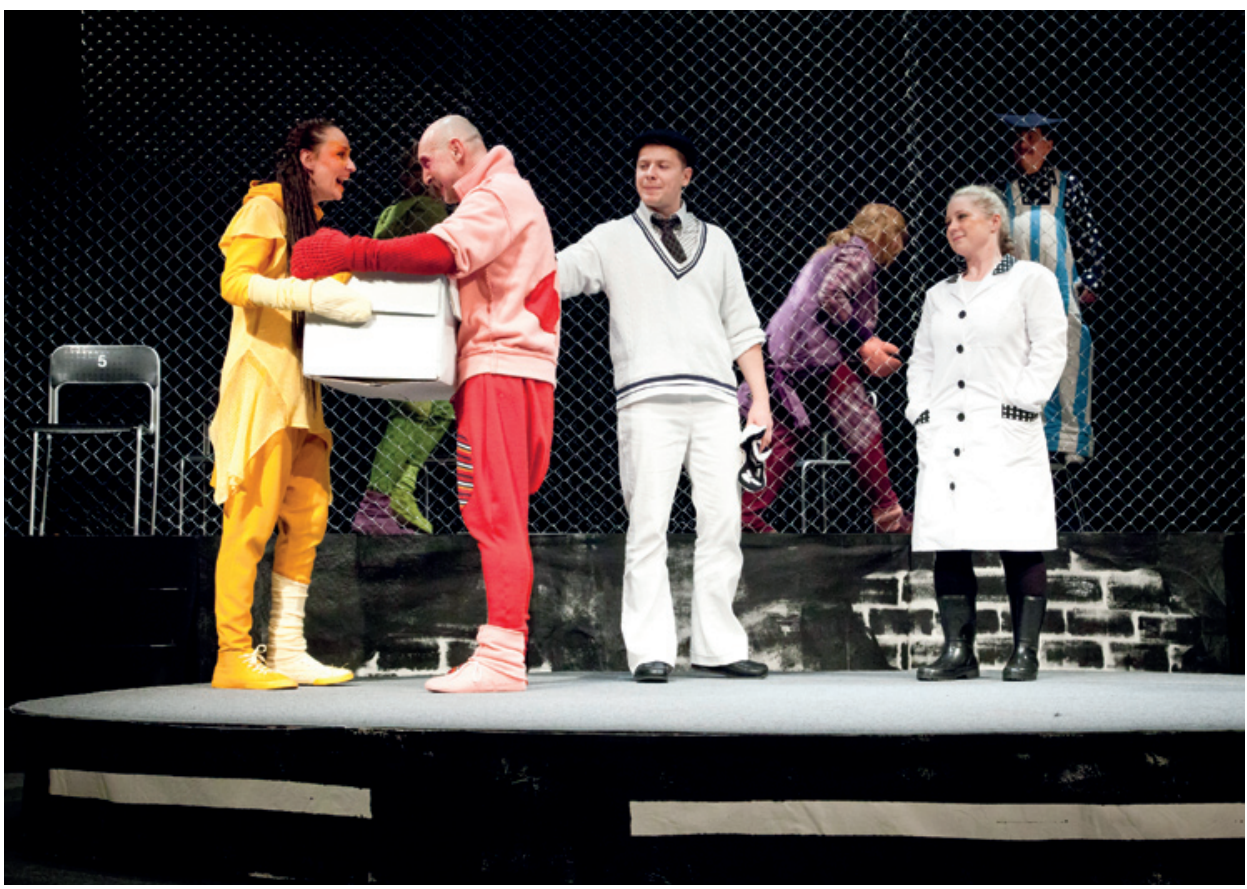

Fig. 3: Pacan - a Story About Love (Pacan- historia o miłości), directed by Jakub Krofta.

Happy Ending. Photograph (C) Natalia Kabanow, reproduced with permission.

At the front, standing left to right: Patrycja Łacina-Miarka (Princess), Marek Tatko (Pacan), Grzegorz Mazon (Marcin), and the nurse Zosia (Marta Kwiek).

At the back, standing left to right: Sławomir Przepiórka (Tolek), Konrad Kujawski (Metal), Józef Frymet (The Elephant Gustaw).

a different actor (with one exception of a short episode) and has a name. They all wear colourful costumes and their faces express multiple emotions, highlighted by colourful make-up, as visible on Natalia Kabanow's production shot (2012).

Such a portrayal of characters invites the emotional engagement; especially given that they all bear the traces of suffering caused by being abandoned by humans. As a case in point, Princess (Patrycja Łacina-Miarka), abandoned because she chewed on the humans' shoes, always scratches herself nervously. Most importantly, however, Wojtyszko's story and Krofta's staging thereof are focused on the misery of Pacan (Marek Tatko), who lost Marcin (Grzegorz Mazoń). The spectators never witness Marcin's misfortunes.

The individualised representation of animals echoes McFarland and Hediger's call to explore animal agency 'in a case-by-case, unique-in-each-instance-fashion' (McFARLAND and HEDIGER 2009: 15-6). The contrast between the precise portrayal of animals and the generalised portrayal of humans works in the opposite direction to the 'logic of domination' that singles out one species (humans) and positions it against 


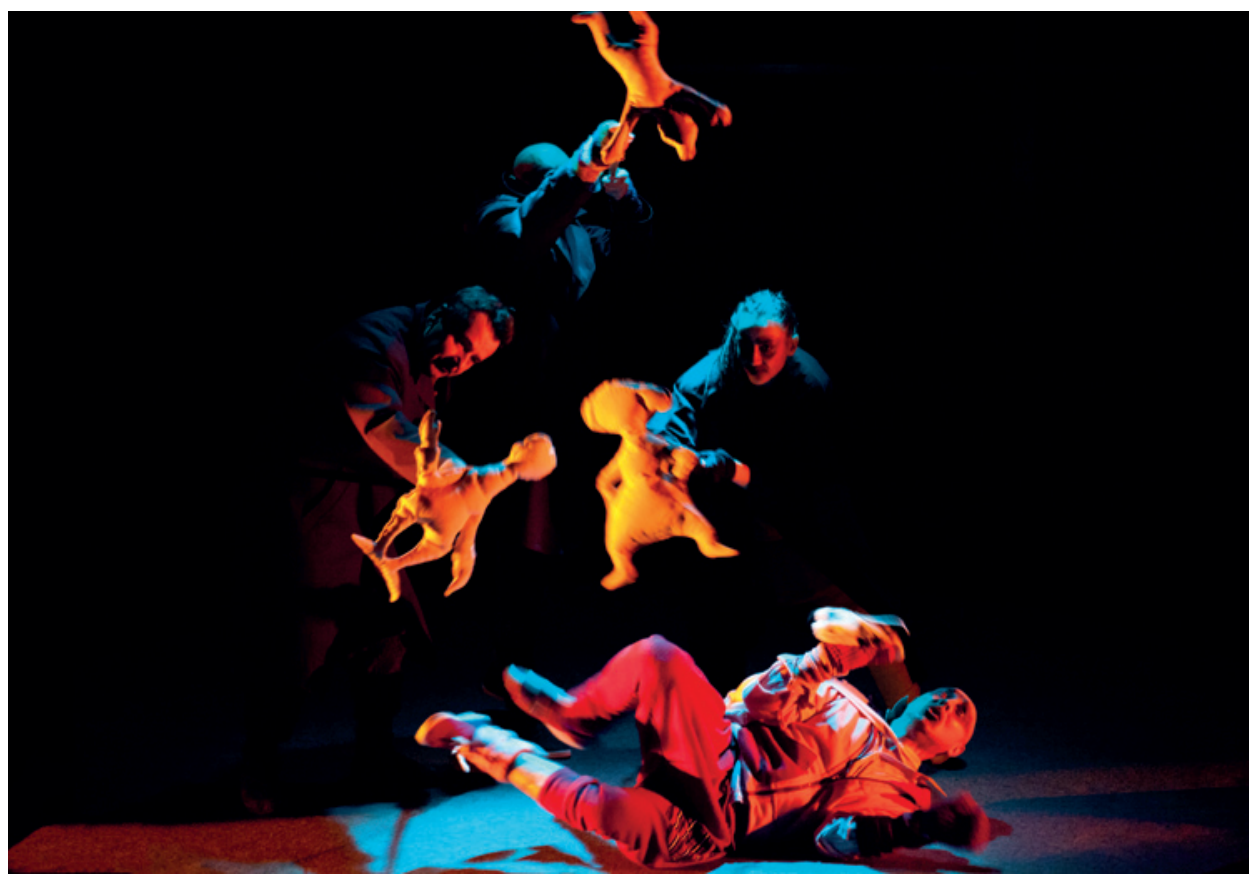

Fig. 4: Pacan - a Story About Love (Pacan- historia o miłości), directed by Jakub Krofta.

Pacan's Dream. Photograph (CNatalia Kabanow, reproduced with permission.

At the front: Marek Tatko (Pacan).

The puppeteers, standing left to right: Krzysztof Grębski,

Sławomir Przepiórka, Patrycja Łacina-Miarka.

a general group of animals. Moreover, in Pacan, humans are presented as inferior to animals. First of all, animals, through their suffering, gain moral superiority. They are also shown as smarter because when the actors-animals speak, the actor-humans act as if they cannot understand them. However the audience can, which again connects the spectators with the animal characters. The animals in Pacan also have longer memories and seem to love more deeply than humans, as is evident at the end, when Marcin finally comes to the shelter. Pacan recognises him immediately, but it takes Marcin some time to see who Pacan is. In fact, Marcin does not recognise the dog until he sees his own hat, which Pacan kept all that time. McFarland and Hediger argue that emotions, morality, memory, and other higher cognitive abilities, are associated with the superiority of human agency over animal agency (MCFARLAND and HEDIGER 2009: 2-6). Therefore Krofta's spectators are invited to imagine a world in which the normative rules of human superiority are turned upside down. In Pacan, animals dominate.

This superiority of animals emphasises the moments during which the audience witnesses humans harming an animal. A particularly striking example of this is 
Pacan's nightmare, which is also the only appearance of the puppets in the production. Hungry and lonely, Pacan dreams about the people who were his family, when he was a puppy. The family is performed in this scene by rod puppets, designed by Zupková and visible on the photograph by Kabanow (2012).

The white colour and lack of facial expressions connect the puppets with other human characters. They look like they are made of pillows to support the frame of the dream, which is important, as it allows the children to read Tatko's emotional reactions to the puppets as believable. The bodies of the puppets are frozen in aggressive poses. For instance, the largest puppet (a father) has its hand raised as if ready to slap. The audience learns about them yelling at him for playing, calling him stupid, giving him the name Pacan (which can be translated into English as 'Lummox'), and finally dumping the puppy in a rubbish bin. Tatko performs Pacan's trauma by waking up from his dream with a loud scream. Fear is visible on his face. The spectators are confronted with the genuine pain of an individual animal caused by cruel humans.

Rods are attached to the back of the puppets and they are manipulated by the actors, who become invisible in black clothes and black hoods (the hoods were used in performance, but are missing from the photograph). Because of this deliberate removal of the puppeteers' corporality from the field of representation, it seems like the puppets are sailing in the air above sleeping Pacan or, perhaps more to the point, the memory of them is hanging over Pacan's head. We are not dealing with a full co-presence here as Tatko does not manipulate the puppets. However, Piris argues that it is the authentic reactions of a human actor to a puppet that facilitates co-presence (PIRIS 2014: 37). Therefore, we can talk about the dream scene as an example of a limited co-presence that still highlights the agency of the puppets, and thereby helps audiences to notice that the family chooses to harm Pacan. Consequently, the spectators can understand that they also have a choice; especially given that, as Klein argues, the audiences of eight-year-olds and upwards compare 'themselves with the characters' pro- and antisocial behaviour' (KLEIN 2010: 117).

The empowerment of the audience to oppose cruelty towards animals is reinforced during the shelter scenes, in which adoption of an animal is presented as a possible solution. The animals in the shelter, separated from the audience by an actual cage, are lonely. While waiting for adoption, the dogs Tolek (Sławomir Przepiórka) and Metal (Konrad Kujawski) are pacing around their boxes. The Elephant Gustaw (Józef Frymet) sits alone in the corner and only when he hears music does he stand up and wave his ears (an action evoked by Frymet through animation of a grey cape) as if dancing. The blind dog Bąbel (Krzysztof Grębski) dies near the end of the performance, because, as he says, he has finally stopped wishing for his own human. This death is represented metaphorically by Grębski hanging Bąbel's hat on the cage, by the nurse Zosia (Kwiek) taking his bowl away, and by Grębski leaving the stage accompanied by the vocalisation of the other actors performing the dogs. Bąbel's death highlights the urgency to act and 
to provide homes for abandoned animals, bringing the production close to Gaard's arguments about ecopedagogy (GAARD 2009: 333-4).

Bąbel's death could have carried particular overtones during the performances accompanied by post-performance workshops Pre-school Doggies (Psiaki przedszkolaki), organised by the charity 2plus4 (collaborating with WTL on that project). The organisation, founded in 2009, looks after abandoned dogs, promotes positive interactions between humans and cats and dogs, and prepares dogs for adoptions (FUNDACJA 2 plus4 2014). During workshops, children and adults could meet actual dogs, learn how to communicate with them (the need for which the production highlighted), and offer a donation for dogs waiting to be adopted (WTL 2014c). By stretching the timeframe of performance related activities, the workshops supported the production's memorability. The presence of the actual dogs, either physical or as a point of reference in promotional materials, also added another layer to the inevitable anthropomorphism of animals in Pacan.

It has to be said that even the audience of the performances without the workshops were offered ideas for post-performance activities. As in Daszeńka, Krofta refers to environmental issues that go beyond human-dog relations to involve older audiences, to provide material for discussions after the performance, and to strengthen memorability of the event. As a case in point, the only animals in the production that never lose hope are the two revolutionary Ferrets (Irmina Annusewicz and Aneta Głuch-Klucznik), who plan an uprising of all animals and want to fight for freedom. Through the Ferrets, Krofta introduces the basic ideas behind various animal liberation movements. Comic qualities of the Ferrets, often achieved through their comments about other characters, engaged, on different levels, both adults and children. The production also highlighted the issue of the animals used for entertainment. While Frymet as the Elephant Gustaw performs his dance, Kujawski as Metal says: 'We don't know if he likes to dance or he does it out of habit', which suggests that Gustaw was broken in by his trainers to dance. Later on, the Filmmaker (Koziar) wants to use Gustaw for a commercial, but laughs, when the nurse Zosia (Kwiek) asks him whether there will be any animal welfare officer on the set. These issues appear in the production for a split moment and, because of that, seem to be directed mainly at the adults, perhaps to encourage them to think about such issues and to offer a starting point for a discussion with their children.

While Daszeńka was a call for responsible interactions, Pacan is a call for help. Building on his target audience's attraction to live actors, to characters and their individual stories, and their emotional subtext, Krofta creates strong emotional links between children and animals. At the same time, through his distancing techniques, he activates the spectators' critical engagement with humans' intentional and unintentional actions - that to various degrees harm animals. In turn, Krofta's aesthetic strategies tune the audience into seeing the cruelty, hearing the animals' appeal for help, and wanting to change the situation. Authentic emotions of actors-as-characters evoked by humans' 
actions (as during Pacan's dream) and highlighted consequences of humans' passivity (like Bąbel's death), emphasise the urgency to reframe human/animal relations through integration instead of separation; an adoption is pointed out as a possible solution. Interestingly, an adoption of an animal could build on Pacan's ecopedagogical aims in terms of developing further emotional connections between humans and the adopted animal, and it could also prompt further exploration of animal agency in the context of a specific animal. As the agencies of each animal in Pacan are individualised and seem superior to human agency, children and adults are also encouraged to challenge the ideas that underlie the 'logic of domination' that characterises normative attitudes towards human/animal relations. Post-performance activities, both offered and suggested by the performance, worked to enhance the memorability of Pacan and to expand its ecopedagogical influences to the world beyond the theatre.

\section{Conclusion}

Krofta's productions engage with an ecopedagogy of everyday life. In both Daszeńka and Pacan the focus is on problems, solutions, and the urgency to act. Both productions' focus on the future is evident in their engagement with young audiences, and their offer of post-performance activities. Both productions use puppets to tune in to the level of their audiences' engagement with the human and animal characters and to give agency to animals and children. In turn, Daszeńka and Pacan teach children to respect the differences between humans and other animals without the 'logic of domination' that Gaard talks about (GAARD 2009: 323). Both productions are also mindful of adult audiences. Through cultural references, humour, and nuance Daszeńka and Pacan facilitate adults' engagement, which strengthens the productions' call for open-minded interactions and conversations as the simplest ways of changing social reality.

The two productions build on theatrical aesthetics, and in particular, the complex aesthetics of puppet theatre, to activate the imaginations of the audiences; this facilitates social and political possibilities of co-presence between the puppets, the actors, and the spectators. Daszeńka and Pacan translate the idea of co-presence into to human/animal relations. Using his, arguably inherently 'Czech', techniques Krofta puts a stepping stone towards 'a democratic community' in Poland that does not consider humans only, but respects and embraces all life - which is in accordance with Gaard's definition of ecopedagogy (GAARD 2009: 334). Both performances show the possibilities of co-presence between puppets, actors, and spectators to create and explore respectful and equal relations between diversified groups. Thus, in a broader sense, they point towards the theatrical and educational potential and importance of puppet theatre in a globalised world. Krofta's theatre engages with one of the main concerns of creating global theatre, which, according to the playwright Mark Ravenhill, is 'how this particular actor with 
this particular audience can use this word or this gesture [to better] capture the sense of being alive at this moment in this city in this culture' (RAVENHILL 2009).

The project continues: under Krofta, the Wrocław Puppet Theatre is not afraid of engaging its audiences of various ages in difficult discussions. Inquires About Sex Life ( $Z$ docieków nad życiem płciowem), directed by Paweł Aigner for adult audiences in 2013, was about sex and language. Later on that year Jarosław Kilian directed What Does a Crocodile Eat For His Dinner? (Co krokodyl jada na obiad?). The production, aimed at audiences of five years old and older, explored again the relationships between humans and animals. Another 2013 production was the eco-feminist Socks and Curl-papers (Skarpety $i$ Papiloty) by Julia Holewińska, one of the most renowned twenty-first-century Polish playwrights, who was commissioned by the WTL to write it. Tomasz Man directed this play for four-year-olds and upwards; it was about a family of foxes, whose mother decides to go back to work. In 2014, Jakub Krofta directed Sam, or Preparation For Family Life (Sam, czyli przygotowanie do życia $w$ rodzinie), written by Maria Wojtyszko. The production, advertised for thirteen-year-olds and upwards, explored, amongst other issues, divorce, religion, and various aspects of parenthood (including abortion and in-vitro fertilisation) (PIEKARSKA 2014). Sam has received a prestigious award for the best production in the Twentieth National Competition for Staging Contemporary Polish Plays; the jury chose Sam over productions from theatres such as Helena Modjeska's National Old Theatre from Cracow (INSTYTUT TEATRALNY 2014c).

Krofta's work is supported by the skills of his actor-puppeteers, who can coexist between various roles and accept the part they play within the larger aim of the production with humility. Together they combine their skills and imagination to explore the possibilities of puppetry and to challenge their audience with difficult topics. This is what theatre is all about! Long may that last.

\section{Bibliography}

BENNETT, Susan. 1997. Theatre Audiences. London: Routledge, 1997.

BURLAND, Karen and Stephanie PITTS. 2014. Postlude. In Karen Burland and Stephanie Pitts (eds.).

Coughing and Clapping: Investigating Audience Experience. Farnham: Ashgate, 2014: 175-9.

ČAPEK, Karel. 1950. Daszeńka, czyli żywot szczeniaka [Dashenka, or the Life of a Puppy]. Transl. by Jadwiga Bułakowska. Warszawa: Nasza Księgarnia, 1950.

ČAPEK, Karel. 2013 [1933]. Dashenka, or the Life of a Puppy. Transl. by M. and R. Weatherall. Redditch: Read Books, 2013.

CAPPS, Donald. 2006. A Time to Laugh: The Religion of Humour. London: Continuum International Publishing Group Ltd., 2006.

ČESKÁ TELEVIZE. 2014. Dášeňka [online]. Praha: Česká televise, 2014 [accessed on Aug 24 ${ }^{\text {th }}$, 2014]. Available at: <http://www.ceskatelevize.cz/porady/898431-dasenka/>. 
CZAJKOWSKA, Anna. 2012. Lekcja wolności w Teatrze na Woli [The Lesson of Freedom on the Wola Theatre Stage] [online]. Warszawa: Instytut Teatralny im. Zbigniewa Raszewskiego, 2012 [accessed on Aug 24 $\left.4^{\text {th }}, 2014\right]$. Available at: <http://www.e-teatr.pl/pl/artykuly/142961.html>.

DAMU. 2014. Directing for Alternative and Puppet Theatre [online]. Praha: Divadelní fakulta AMU, 2014 [accessed on Aug 24 ${ }^{\text {th }}$, 2014]. Available at: <http://www.damu.cz/en/m-a-degree-programs/directing-for-alternative-and-puppet-theatre-1>.

DEJVICE THEATRE. 2014. Spoonriverská Antologie [Spoon River Anthology] [online]. Dejvice Theatre: Praha, 2014 [accessed on Aug 24 ${ }^{\text {th }}, 2014$ ]. Available at: <http://www.dejvickedivadlo.cz/ archiv-titulu?spoonriverska-antologie>.

DERKACZEW, Joanna. 2011. Mała wielka Daszeńka [Little Great Daszeńka] [online]. Warszawa: Instytut Teatralny im. Zbigniewa Raszewskiego, 2011 [accessed on Aug 24 ${ }^{\text {th }}, 2014$ ]. Available at: $<$ http://www.e-teatr.pl/pl/artykuly/121131.html >.

DRAK THEATRE. 2014. Jakub Krofta [online]. Divadlo Drak: Hradec Králové, 2014 [accessed on Aug 24 $\left.{ }^{\text {th }}, 2014\right]$. Available at: <http://www.draktheatre.cz/235>.

DRAK THEATRE. 2015b. Všechno litá, co peří má [The Flying Babies] [online]. Divadlo Drak: Hradec Králové, 2015 [accessed on Feb 20 ${ }^{\text {th }}$, 2015]. Available at: <http://draktheatre.cz/repertoar/ vsechno-lita-co-peri-ma/>.

EPSTEIN, Richard. 2004. Animals as Objects, or Subjects, of Rights. In Cass R. Sunstein and Martha C. Nussbaum (eds.). Animal Rights: Current Debates and New Directions. Oxford: Oxford UP, 2004: 143-61.

EUROPEAN UNION. 2007. Treaty of Lisbon. Official Journal of the European Union. 50 (2007) [accessed on Jan $27^{\text {th }}$, 2015]. Available online at: < http://eur-lex.europa.eu/legal-content/EN/TXT/ PDF/?uri=OJ:C:2007:306:FULL\&from=EN $>$.

FRANCIS, Penny. 2011. Puppetry: A Reader in Theatre Practice. London: Routledge, 2011.

FUNDACJA 2PLUS4. 2014. O nas [About Us] [online]. Wrocław: Fundacja 2plus4, 2014 [accessed on Aug $\left.24^{\text {th }}, 2014\right]$. Available at: <http://www.2plus4.org/o-nas/o-fundacji $>$.

GAARD, Greta. 2009. Children's environmental literature: from ecocriticism to ecopedagogy. Neohelicon. 36 (2009): 2: 321-34.

INSTYTUT TEATRALNY. 2014a. Petr Nosálek [online]. Warszawa: Instytut Teatralny im. Zbigniewa Raszewskiego, 2014 [accessed on Aug 24 ${ }^{\text {th }}$, 2014]. Available at: <http://www.e-teatr.pl/pl/ osoby/10820.html>.

INSTYTUT TEATRALNY. 2014b. Jan Polivka [online]. Warszawa: Instytut Teatralny im. Zbigniewa Raszewskiego, 2014 [accessed on Aug 24 ${ }^{\text {th }}$, 2014]. Available at: $<$ http://www.e-teatr.pl/pl/ osoby/45631,karierateatr.html\#start>.

INSTYTUT TEATRALNY. 2014c. Warszawa. Laureaci 20. Ogólnopolskiego Konkursu na Wystawienie Polskiej Sztuki Wspótczesnej [Warsaw. The Laureates of the $20^{\text {th }}$ National Competition for Staging Contemporary Polish Plays] [online]. Warszawa: Instytut Teatralny im. Zbigniewa Raszewskiego, 2014 [accessed on Aug 24 $4^{\text {th }}, 2014$ ]. Available at: $<$ http://www.e-teatr.pl/pl/artykuly/185788.html $>$.

KABANOW, Natalia. 2012. Production shots of Pacan- historia o miłości [Pacan - a Story About Love]. Premiere in Wrocławski Teatr Lalek, Wrocław, on November $24^{\text {th }}, 2012$. Wrocławski Teatr Lalek, Wrocław. 
Kasia Lech

Puppets, Dogs, and Vegetarian Angels: Ecocriticism in Jakub Krofta's Polish Productions

KLEIN, Jeanne. 2010. From Children's Perspectives: A Model of Aesthetic Processing in Theatre. Journal of Aesthetic Education. 39 (2005): 4: 40-57 [accessed on Aug 24 ${ }^{\text {th }}, 2014$ ]. Available online at <http://www.jstor.org/stable/3527391>.

KLEIN, Jeanne. 2010. Mediating Childhood: How Child Spectators Interpret Actors' Bodies in Theatrical Media. In Leni Marshall and Valerie Barnes Lipscomb (eds.). Staging Age: The Performance of Age in Theatre, Dance, and Film. Basingstoke: Palgrave Macmillan, 2010: 109-27.

KOZICZYŃSKI, Bartek. 2009. 333 popkulturowe rzeczy PRL [333 Pop Culture Things From the Polish People's Republic]. Czerwonak: Vesper, 2009.

KROFTA, Jakub. 2011. Digital recording of Daszeńka, czyli żywot szczeniaka [Dashenka, or the Life of a Puppy]. Premiere in Teatr Lalka, Warszawa, on May 21 ${ }^{\text {st }}, 2011$. Teatr Lalka, Warszawa.

KROFTA, Jakub. 2012. Digital recording of Pacan-historia o miłości [Pacan - a Story About Love]. Premiere in Wrocławski Teatr Lalek, Wrocław, on November $24^{\text {th }}, 2012$. Wrocławski Teatr Lalek, Wrocław.

KROFTA, Jakub. 2014. International Theatre Project 'Jánošík, Janosik, Jánošik' [online]. Divadlo Drak: Hradec Králové, 2014 [accessed on Aug 24 ${ }^{\text {th }}, 2014$ ]. Available at: <http://www.draktheatre.cz/223>.

LALKA Theatre. 2014. Daszeńka [online]. Warszawa: Teatr Lalka, 2014 [accessed on Aug 24 ${ }^{\text {th }}$, 2014]. Available at: <http://www.teatrlalka.waw.pl/p_daszenka.php>.

MATUSZEWSKA, Małgorzata. 'Pacan' - sobotnia premiera we Wrocławskim Teatrze Lalek ['Pacan' - Saturday's Premiere in the Wrocław Puppet Theatre] [online]. Wrocław: Gazeta Wrocławska, 2012 [accessed on Aug 24 $4^{\text {th }}, 2014$ ]. Available at: <http://www.gazetawroclawska.pl/ artykul/704917,pacan-sobotnia-premiera-we-wroclawskim-teatrze-lalek,id,t.html >.

MAY, Regine. 2006. Apuleius and Drama: The Ass on Stage. Oxford: Oxford UP, 2006.

MCCASLIN, Nellie. 2005. Seeking the Aesthetic in Creative Drama and Theatre for Young Audiences. Journal of Aesthetic Education. 39 (2005): 4: 12-9 [accessed on Aug 24 ${ }^{\text {th }}$, 2014]. Available online at <http://www.jstor.org/stable/3527388>.

MCFARLAND, Sarah and Ryan HEDIGER. 2009. Approaching the Agency of Other Animals: an Introduction. In Sarah McFarland and Ryan Hediger (eds.). Animals and Agency: An Interdisciplinary Exploration. Leiden: Brill, 2009: 1-22.

NICHOLSON, Helen. 2009. Theatre \& Education. Basingstoke: Palgrave Macmillan, 2009.

NONHUMAN RIGHTS PROJECT. 2013. Mission, Goals \& Values [online]: Nonhuman Rights Project, 2013 [accessed on Jan $28^{\text {th }} 2015$ ]. Available at: <http://www.nonhumanrightsproject. org/mission-goals-values/>.

NUSSBAUM, Martha C. 2009. Frontiers of Justice: Disability, Nationality, Species Membership. Boston: Harvard University Press, 2009.

PIEKARSKA, Magda. 2011. Rozwód z happy endem. Takie rzeczy tylko w teatrze? [Divorce with happy ending. Is it possible only in theatre?] [online]. Warszawa: Instytut Teatralny im. Zbigniewa Raszewskiego, 2011 [accessed on Aug 24 ${ }^{\text {th }}$, 2014]. Available at: <http://www.e-teatr.pl/pl/ artykuly/178897.html>.

PIRIS, Paul. 2014. Co-presence and Ontological Ambiguity of the Puppet. In Dassia N. Posner, Claudia Orenstein, and John Bell (eds.). The Routledge Companion to Puppetry and Material Performance. London: Routledge, 2014: 30-42. 
RAVENHILL, Mark. 2009. Foreword. In Dan Rebelatto. Theatre \& Globalization. Basingstoke: Palgrave Macmillan, 2009: ix-xix.

RFI. 2015. France updates laws on animal feelings [online]. Paris: France Médias Monde, 2015 [accessed on Jan 28 $8^{\text {th }}$ 2015]. Available at: <http://www.english.rfi.fr/france/20150129-france-updates-laws-animal-feelings>.

STATES, Bert O. 1985. Great Reckonings in Little Rooms. London: University of California Press, 1985.

SZYDŁOWSKA, Agnieszka. 2011. Powrót Daszeńki [Daszeńka’s Come Back] [online]. Warszawa: Instytut Teatralny im. Zbigniewa Raszewskiego, 2011 [accessed on Aug 24 ${ }^{\text {th }}, 2014$ ]. Available at: $<$ http://www.e-teatr.pl/pl/artykuly/117852.html>.

USAREWICZ, Hanna. 2012. Z divadla do teatru [From Divadlo to Theatre] [online]. Warszawa: Instytut Teatralny im. Zbigniewa Raszewskiego, 2012 [accessed on Aug 24 ${ }^{\text {th }}$,2014]. Available at: $<$ http://www.teatr-pismo.pl/ludzie/263/z_divadla_do_teatru/ $>$.

WARZECHA, Bartek. 2011. Production shot of Daszeńka, czyli żywot szczeniaka [Dashenka, or the Life of a Puppy]. Premiere in Teatr Lalka, Warszawa, on May 21 ${ }^{\text {st }}, 2011$. Teatr Lalka, Warszawa.

WASZKIEL, Halina. 2014. In Andrzej Matul and Konrad Szczebiot. Lalka może zagrać wszystko [radio podcast]. Warszawa: Polskie Radio S.A., 2014. Recorded during the programme on April $23^{\text {rd }}, 2014$ [accessed on Aug 24 ${ }^{\text {th }}, 2014$ ]. Available at: <http://www.polskieradio.pl/8/402/ Artykul/1107532,Lalka-moze-zagrac-wszystko>.

WTL. 2014a. Dyrekcja [Management] [online]. Wrocław: Wrocławski Teatr Lalek, 2014 [accessed on Aug 24 $\left.4^{\text {th }}, 2014\right]$. Available at: <http://www.teatrlalek.wroclaw.pl/o-teatrze/ludzie-wtl/dyrekcja >.

WTL. 2014b. Pacan - historia o miłości [Pacan - a Story About Love] [online]. Wrocław: Wrocławski Teatr Lalek, 2014 [accessed on Aug 24 ${ }^{\text {th }}, 2014$ ]. Available at: <http://www.teatrlalek.wroclaw.pl/ spektakle/dla-dzieci/pacan-historia-o-milosci>.

WTL. 2014b. Pacan - historia o miłości i warsztaty z psiakami [Pacan - a Story About Love and the Workshops with Doggies] [online]. Wrocław: Wrocławski Teatr Lalek, 2014 [accessed on Aug $\left.24^{\text {th }}, 2014\right]$. Available at: <http://www.teatrlalek.wroclaw.pl/aktualnosci/item/173-pacan-historia-o-milosci-i-warsztaty-z-psiakami/173-pacan-historia-o-milosci-i-warsztaty-z-psiakami>.

WYATT, Caroline. 2015. Should ritual slaughter be banned in the UK? [online]. London: BBC, 2015 [accessed on Feb 16 ${ }^{\text {th }}$,2015] Available at: < http://www.bbc.co.uk/news/uk-31411219>.

ZAWORSKA, Joanna. 2011. Dorośli na widowni, czyli teatr dla dzieci [Adults in the Auditorium or Children's Theatre] [online]. Warszawa: Instytut Teatralny im. Zbigniewa Raszewskiego, 2011 [accessed on Aug 24 $4^{\text {th }}, 2014$ ]. Available at: <http://www.e-teatr.pl/pl/artykuly/125992.html>. 


\section{Summary}

This article explores the work of Czech theatre director Jakub Krofta in the context of ecocriticism. This discussion focuses on Krofta's two productions directed for Polish puppetry theatres and aimed at young audiences: Daszeńka (Teatr Lalka, Warsaw, 2011), based on Karel Čapek’s book, and Pacan - historia o miłości (Pacan - a story about love; Wrocławski Teatr Lalek, Wrocław, 2012). My analysis is framed by Greta Gaard's theories on ecopedagogy (GAARD 2009) and Paul Piris's discussion on co-presence between the puppeteer and the puppet (PIRIS 2014). Building on their work, and combining it with performance analyses of both productions, this article explores how Krofta manages interactive relationships between performers, puppets, and spectators so as to engage his audiences with global discussions relating to human/environment relations. Krofta's works achieve this through their exploration of the problematic status of animals in the contemporary world, invitation the renegotiation of relations between humans and animals, and facilitation of various degrees of engagement for both children and adults.

\section{Keywords}

Jakub Krofta, Polish puppet theatre, Czech puppet theatre, ecocriticism, theatre phenomenology, theatre theory, audience perception, young audiences

DOI: $10.5817 /$ TY2015-2-7

Katarzyna Lech (kasia.lech@canterbury.ac.uk) is Senior Lecturer in the School of Music and Performing Arts at the Canterbury Christ Church University, Canterbury, UK. Prior to her arrival at CCCU in 2013, Kasia worked as a Lecturer in Drama at University College Dublin in Ireland and as an Assistant Lecturer in Verse Speaking at the Ludwik Solski State Drama School in Wrocław, in Poland. Kasia trained as an actor in puppetry and has performed in numerous productions in Poland and Ireland, including starring as the Grey Cat, a puppet that co-hosted a live TV show for children CyberMysz on Polish national television. Kasia is a co-founder and the Artistic Liaison of Polish Theatre Ireland - a multicultural theatre company based in Dublin. She holds a PhD from University College Dublin. She has published on verse and verse drama in contemporary performance, Polish and Irish theatres, and translation. Her research interests also include actor training, performance of poetry, and, recently, theatre and animal rights. 